\title{
Lack of genetic structure in Kentish Plover Charadrius alexandrinus from the Iberian coast. What's wrong with the endangered north-western population?
}

\author{
MARÍA VIDAL, MARÍA A. HERNÁNDEZ, ANTONIO LUIS and \\ JESÚS DOMÍNGUEZ
}

\begin{abstract}
Summary
Coastal wader species are sensitive to anthropogenic activity and habitat change along the coastal edge, which has been responsible for the decline in the populations of these birds. Correct management requires knowledge of the pattern and scale of genetic variation within and among populations as well as the relationships between population dynamics and genetic structure. We investigated these factors in the Kentish Plover Charadrius alexandrinus from the Iberian coast to determine the degree of vulnerability of the endangered north-western population. We analysed the genetic structure and gene flow using a 631-bp fragment of the mitochondrial (mtDNA) control region and eight microsatellite markers in 113 unrelated individuals from 31 Iberian beaches. The results do not support the recent decline hypothesis because there was no evidence of a bottleneck, but they do support a population expansion along the Atlantic coast. We found no genetic structure or isolation-by-distance, in agreement with results recently observed on a continental scale. However, explanations for high continental gene flow, such as temporary breeding habitats and high breeding dispersal, do not seem to apply to the Galician population. Galician Kentish Plovers breed solely on beaches, a suitable and more predictable habitat during the breeding period than ephemeral inland wetlands, and female movements during the breeding period are uncommon, mainly due to the extremely low hatching success. This study suggests a demographic connectivity between Portuguese and Galician populations that is referred to as source-sink population dynamics, in which individuals dispersing from Portugal support the Galician coastal population. This dispersal pattern highlights the importance of supranational management plans to protect endangered species.
\end{abstract}

\section{Introduction}

Coastal waders are sensitive to the conservation status of the coastal edge (Ferns 1992) where anthropogenic activity causes many changes to the ecosystem. The European Union breeding wader populations declined by $55 \%$ from 1990 to 2000 (BirdLife International 2004a). To manage these populations, we need to quantify the pattern and scale of genetic variation within and among populations and examine the relationships between population dynamics and genetic structure (Avise 2000). Inland nesting wader species that use continentally distributed wetlands appear to be less structured (more often panmictic) than long-distance migrant waders that breed in the Arctic (Verkuil et al. 2012). The Kentish Plover Charadrius alexandrinus is a wader that inhabits temperate coasts and inland wetlands in Eurasia and North Africa, although its breeding 
distribution in Europe is predominantly coastal (Delany et al. 2009). The IUCN Red List of Threatened Species considers it as "Least Concern" with a decreasing population trend (IUCN 2013). At the continental scale, mainland breeding sites revealed a very low level (or complete lack) of genetic differentiation (Küpper et al. 2012); however, the genetic connectivity within areas such as the Iberian Peninsula, which supports $16-24 \%$ of European breeding birds, is not known (BirdLife International 2004b).

The Iberian coastal breeding population of the Kentish Plover is located along the Mediterranean and Atlantic coasts (Felgueiras 2008, Amat 2012), although the northern and north-western Spanish population is very small and restricted to the Galician coast, with only 101 pairs in 2010 (Vidal and Domínguez 2013). Previously, northern Spain (Asturias, Cantabria and País Vasco) harboured a small breeding population that disappeared in the late 1970s (Álvarez-Balbuena 2000). The inland breeding populations of Spain (Amat 2012) and Portugal (Felgueiras 2008) are scarce and widely scattered. The Galician population, listed in the Galician Endangered Species List, was affected by the Prestige oil spill that occurred in 2002, one of the largest spills ever experienced in Europe (Albaigés et al. 2006, Vidal and Domínguez 2013). From 1988 to 2010, the Galician population declined until 2004 and then experienced a moderate increase (Vidal and Domínguez 2013). The population growth from 2005 to 2010 was attributed to the combination of three main factors: successful management strategies undertaken at many of the Galician Kentish Plover breeding beaches after the Prestige oil spill, changes occurring in the spatial distribution of the breeding pairs and immigration of birds from other sites (Vidal and Domínguez 2013). Movements between the Portuguese and Galician coasts observed for colour-ringed birds (Domínguez and Vidal 2008) and the continental panmictic pattern (Küpper et al. 2012) suggest genetic connectivity along the Iberian Atlantic coast and, probably, the entire Iberian Peninsula. This connectivity may be critical to the viability of the Galician population, which is characterised by very low productivity (10.3\% of nests hatched and $26 \%$ of hatched chicks fledged in the last 15 years; Vidal and Domínguez unpubl. data), below values reported in stable populations from other breeding localities in Spain (Ballesteros and Torre 1993, Oltra and Gómez 1995, Fraga and Amat 1996, Toral and Figuerola 2012), Portugal's west coast (Norte and Ramos 2004), France's Atlantic coast (Lang and Typlot 1985), southern Hungary (Székely 1992), United Arab Emirates (Kosztolanyi et al 2009) and North Africa (Hanane 2011).

The literature contains a weak understanding of the Iberian breeding population trend. Some authors indicate that the Spanish population has declined over the last few decades (BirdLife International 2004b, Delany et al. 2009), while others define the data for Spanish and Portuguese populations as insufficient to establish national trends (Figuerola et al. 2004, Felgueiras 2008). If there was a reduction then it may be manifested as a genetic bottleneck and by a reduction in genetic diversity, the effects of which are well known (Frankham 2005). Thus, we investigate the degree of genetic differentiation within and between coastal Kentish Plover populations in the Iberian Peninsula while also identifying and evaluating evidence for recent bottlenecks. Moreover, given the peripheral position of the Galician population in the Atlantic Iberian context, we characterized the genetic structure of breeding populations of the Kentish Plover in Iberian Peninsula as a whole. Significant genetic differentiation of the north-western population would suggest limited demographic connectivity and emphasise the importance of this small population.

\section{Study area and methods}

Kentish Plovers ( $n=113 ; 33$ males and 80 females) were captured on 31 Iberian beaches between 2005 and 2009. The beaches were clustered by geographical proximity into 1o populations, seven along the Atlantic coast of Spain and Portugal and the others along the Spanish Mediterranean coast (Figure 1, Table I; Table $S_{1}$ in the online supplementary materials). Our analyses focused on two levels: a primary level that evaluated these 1o populations and a secondary level in which the data were grouped by Atlantic or Mediterranean coast. All of the samples were collected 


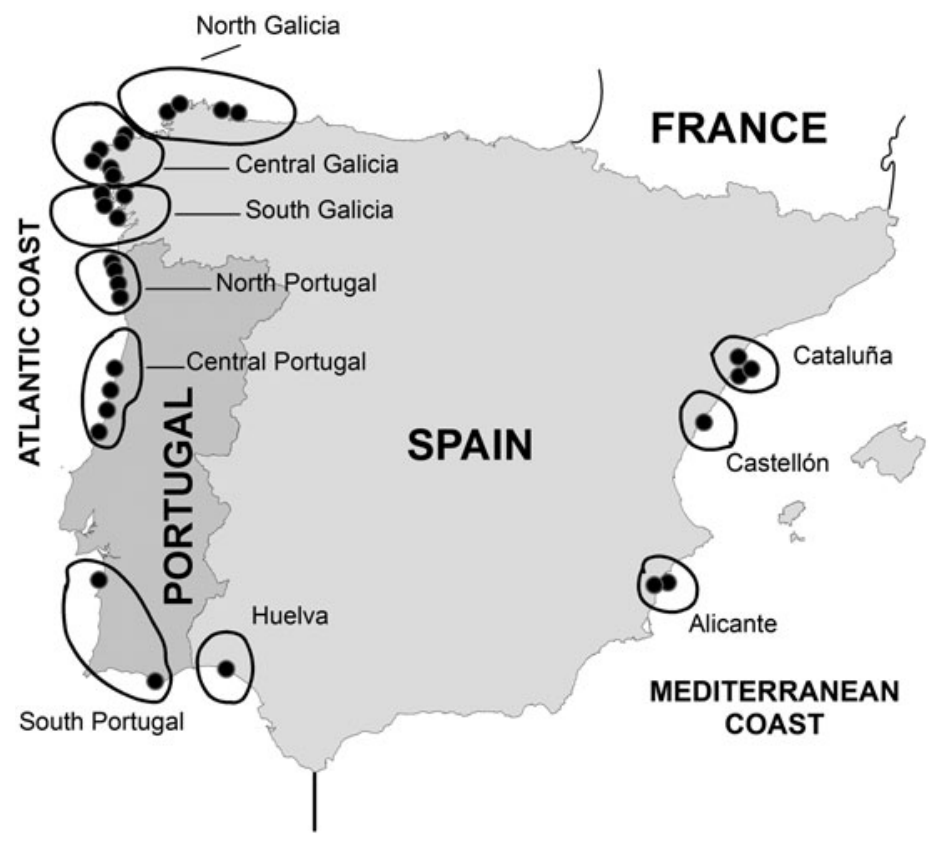

Figure 1 . Kentish Plover sampling sites (beaches) used in this study. The beaches are clustered by geographical proximity into 10 a priori populations.

from adult breeding birds captured at the nest using a funnel trap. No known close relatives (parents, offspring, siblings, etc.) were included in the analyses. A small amount of blood (o.I ml) was extracted from each bird by puncturing the brachial vein. Blood samples were subsequently stored and purified using FTA Classic Cards ${ }^{\circledR}$ (Smith and Burgoyne 2004). Total DNA from FTA ${ }^{\circledR}$ cards blood samples was extracted with ammonium acetate. A piece of the dried blood sample (approximately $2 \mathrm{~mm}^{2}$ ) was cut away using a sterile cutter and transferred to a microcentrifuge tube and incubated in $250 \mu \mathrm{l} \mathrm{SET} \mathrm{buffer} \mathrm{(0.15} \mathrm{M} \mathrm{NaCl,} \mathrm{0.05} \mathrm{M} \mathrm{Tris} \mathrm{pH} 7.5,0.001 \mathrm{M} \mathrm{EDTA}$ ) at $4^{\circ} \mathrm{C}$ for $5 \mathrm{~h}$. The sample was then treated with $7 \mu \mathrm{l}$ of SDS (sodium dodecyl sulphate) $20 \%$ and $5 \mu \mathrm{l}$ of proteinase $\mathrm{K}$ (10 $\mathrm{mg} / \mathrm{ml}$ ) at $55^{\circ} \mathrm{C} \mathrm{o} / \mathrm{n}, 250 \mu \mathrm{l}$ of ammonium acetate $4 \mathrm{M}$ was added to the mixture and left at room temperature for 30 min after which the suspension was centrifuged for Io $\mathrm{min}$ at $13,500 \mathrm{rpm}$. The supernatant was transferred to a new microcentrifuge tube and DNA was precipitated by adding $1 \mathrm{ml}$ of absolute ethanol and $10 \%(\mathrm{v} / \mathrm{v})$ sodium acetate $3 \mathrm{M}$. After centrifugation, the air-dried DNA pellet was resuspended in $4 \mathrm{O} \mu \mathrm{l}$ of $\mathrm{ddH}_{2} \mathrm{O}$.

\section{Mitochondrial sequences}

A fragment of 631 bp of cytochrome $b$ was amplified from mitochondrial DNA using primers L14990 (AACATCTCCGCATGATGAAA) and Hi5696 (AATAGGAAGTATCATTCGGGTTT GATG) (Joseph et al. 1999). PCR amplification was performed in a GeneAmp ${ }^{\text {TM }}$ PCR System (Applied-Biosystems). The sample volume was $25 \mu$ l containing 0.3 units of Taq polymerase (Bioline) Io x PCR buffer, dNTPs $0,192 \mathrm{mM}, 1,9 \mathrm{mM} \mathrm{MgCl}_{2}$ y $0,2 \mu \mathrm{M}$ of each primer. The PCR profile used was one cycle of $94{ }^{\circ} \mathrm{C}$ for II min followed by 30 cycles of $94{ }^{\circ} \mathrm{C}$ for $35 \mathrm{~s}, 48{ }^{\circ} \mathrm{C}$ for $60 \mathrm{~s}, 72^{\circ} \mathrm{C}$ for $60 \mathrm{~s}$, and a final extension for $10 \mathrm{~min}$ at $72{ }^{\circ} \mathrm{C}$.

The PCR products were purified with II $\mu \mathrm{l}$ of $8 \mathrm{M} \mathrm{NH}_{4} \mathrm{Ac}$ and $33 \mu \mathrm{l}$ ethanol, and the precipitate was resuspended in $14 \mu \mathrm{l}$ of $\mathrm{ddH}_{2} \mathrm{O}$. The BigDye terminator AmpliCycle ${ }^{\circledR}$ sequencing kit was used. After purification with ethanol and sodium acetate, the samples were loaded onto an 
Table 1. Genetic diversity measures for Kentish Plover mitochondrial and microsatellite data sets. $n$, sample size; $\mathrm{N}_{\mathrm{h}}$, number of haplotypes; $\mathrm{h}$, haplotype diversity, $\pi$, nucleotide diversity; $\mathrm{A}$, mean number of alleles per locus $\left(\mathrm{x} \pm \mathrm{SD}\right.$ ); $R_{S}$, allelic richness based on rarefaction; $H_{\mathrm{O}}$, observed heterozygosity; $H_{\mathrm{E}}$, expected heterozygosity; $F_{\mathrm{IS}}$, within subpopulation inbreeding coefficient.

\begin{tabular}{|c|c|c|c|c|c|c|c|c|c|c|}
\hline \multirow[t]{2}{*}{ Population } & \multicolumn{4}{|c|}{ Mitochondrial } & \multicolumn{6}{|c|}{ Microsatellites } \\
\hline & $\mathrm{n}$ & $\mathrm{N}_{\mathrm{h}}$ & h & $\pi$ & $\mathrm{n}$ & A & $R_{\mathrm{S}}$ & $H_{\mathrm{O}}$ & $H_{\mathrm{E}}$ & $F_{\text {IS }}$ \\
\hline North Galicia (NG) & 5 & 2 & 0.400 & 0.00063 & 4 & $4.75 \pm 1.09$ & 4.71 & 0.844 & 0.826 & -0.0253 \\
\hline Central Galicia (CG) & 27 & 3 & 0.211 & 0.00034 & 31 & $10.0 \pm 3.54$ & $4 \cdot 38$ & 0.726 & 0.776 & 0.0661 \\
\hline South Galicia (SG) & 12 & 3 & 0.439 & 0.00074 & 13 & $8.0 \pm 3.0$ & $4 \cdot 49$ & 0.683 & 0.801 & 0.1531 \\
\hline North Portugal (NP) & 9 & 2 & 0.222 & 0.00035 & 11 & $6.62 \pm 1.99$ & $4 \cdot 35$ & 0.784 & 0.765 & -0.0281 \\
\hline Central Portugal (CP) & 12 & 6 & 0.848 & 0.00204 & 13 & $7.75 \pm 2.90$ & 4.63 & 0.644 & 0.789 & 0.1724 \\
\hline South Portugal (SP) & 3 & 1 & $\mathrm{O}$ & $\mathrm{O}$ & 5 & $5 \cdot 37 \pm 1.73$ & 4.75 & 0.750 & 0.811 & 0.0840 \\
\hline Huelva $(\mathrm{H})$ & 8 & 2 & 0.250 & 0.0004 & 8 & $6.37 \pm 1.49$ & 4.69 & 0.750 & 0.816 & 0.0857 \\
\hline Alicante (AL) & 5 & 1 & o & $\mathrm{O}$ & 5 & $5.12 \pm 1.54$ & 4.60 & 0.725 & 0.817 & 0.1245 \\
\hline Castellón (CS) & 4 & 1 & o & $\mathrm{O}$ & 4 & $3.75 \pm 0.97$ & 3.75 & 0.594 & 0.701 & 0.1739 \\
\hline Cataluña (CT) & 11 & 2 & 0.182 & 0.00029 & 11 & $6.87 \pm 2.52$ & 4.45 & 0.648 & 0.789 & 0.1869 \\
\hline
\end{tabular}

ABI PRISM ${ }^{\circledR}$ 3130XL GeneticAnalyzer (Applied Biosystems). The sequences were edited using BioEdit 7.0.9.o software (Hall 1999). The final alignment contained 631 bp of data from 96 birds sampled in 10 Spanish and Portuguese populations (Table $I$ and Figure I).

\section{Microsatellites}

Samples were genotyped for eight microsatellites using primer sequences specific for the Kentish Plover. Four of these sequences were described by Küpper et al. (2007): Calex-02 $\left(\mathrm{T}_{\mathrm{a}}=57^{\circ} \mathrm{C}\right)$; Calex-22 $\left(\mathrm{T}_{\mathrm{a}}=59^{\circ} \mathrm{C}\right) ;$ Calex-32 $\left(\mathrm{T}_{\mathrm{a}}=62^{\circ} \mathrm{C}\right)$ and Calex-39 $\left(\mathrm{T}_{\mathrm{a}}=62^{\circ} \mathrm{C}\right)$. Another four were described by Funk et al (2007): $\mathrm{C} 201\left(\mathrm{~T}_{\mathrm{a}}=52^{\circ} \mathrm{C}\right) ; \mathrm{C} 203\left(\mathrm{~T}_{\mathrm{a}}=52^{\circ} \mathrm{C}\right) ; \mathrm{C}_{2} \mathrm{O} 4\left(\mathrm{~T}_{\mathrm{a}}=52^{\circ} \mathrm{C}\right) ; \mathrm{C}_{20} \mathrm{O}$ $\left(\mathrm{T}_{\mathrm{a}}=52^{\circ} \mathrm{C}\right)$. The sample volume was $25 \mu \mathrm{l}$ containing 0.3 units of Taq polymerase (Bioline), primer $5 \mathrm{uM}$, Iox PCR Buffer, dNTPs $2 \mathrm{mM}, \mathrm{Mg} 25 \mathrm{mM}$, DNA 1ong,. The PCR profile used was one cycle of $93^{\circ} \mathrm{C}$ for $12 \mathrm{~min}$ followed by 35 cycles of $93^{\circ} \mathrm{C}$ for 30 , annealing temperature (written above for each primer) for $30 \mathrm{~s}, 72^{\circ} \mathrm{C}$ for $60 \mathrm{~s}$, and a final extension for 10 min at $72^{\circ} \mathrm{C}$. After purification with ethanol and sodium acetate, the samples were loaded onto an ABI PRISM ${ }^{\circledR}$ 3130XL GeneticAnalyzer (Applied Biosystems). ABIPRISM ${ }^{\circledR}$ GeneMapper $^{\mathrm{TM}}$ Version 3.0 was used to analyse data. The final microsatellite data set contained genotypes from 105 individuals sampled from 10 populations (Table 1 and Figure 1 ).

\section{Genetic diversity patterns}

The haplotype (h), nucleotide diversity values $(\pi)$ and the number of polymorphic sites (s) were calculated for the mitochondrial sequence data using the DNAsp 5.0 software (Librado and Rozas 2009). The observed and expected heterozygosity values ( $H_{\mathrm{O}}$ and $H_{\mathrm{E}}$, respectively) were calculated for the microsatellite data using the ARLEQUIN 3.5 software (Excoffier and Lischer 2010)

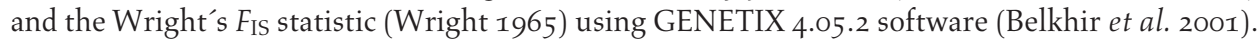

Tests for deviations from Hardy-Weinberg (HWE) genotypic proportions (Guo and Thompson 1992) and for linkage disequilibrium were performed using ARLEQUIN. To identify significant departures from HWE and linkage disequilibrium, the Benjamini and Hochberg correction for multiple comparisons was used (Benjamini et al. 2001).

The presence of null alleles, allele dropout and stutter bands were assessed using MICROCHECKER (Van Oosterhout et al. 2004). The allelic richness $\left(R_{\mathrm{S}}\right)$, an index of the number of alleles corrected for sample size using rarefaction, and private allelic richness, a convenient measure of how distinct a population is from other populations, were calculated using HP-RARE 
(Kalinowski 2005) for the primary and secondary levels. The small sample sizes used to obtain $R_{\mathrm{S}}$ were 8 and 40 alleles, respectively.

\section{Genetic structure analyses}

Microsatellite data were analysed using analysis of molecular variance (AMOVA) with ARLEQUIN 3.5 software (Excoffier and Lischer 2010). Pairwise mitochondrial and microsatellite values, $\Phi_{\mathrm{ST}}$ and $F_{\mathrm{ST}}$, respectively, were also obtained for each combination of the 1o populations examined. One thousand random permutations were used. $P$ values from the pairwise tests were evaluated using the Benjamini and Hochberg correction for multiple comparisons (Benjamini et al. 2001).

We used a Bayesian clustering approach implemented in the program STRUCTURE, version 2.3.4 (Pritchard et al. 2000), to infer the number of populations $(K)$ in a sample and to assign individuals to one or more of these populations as suggested by the microsatellite data. An admixture model and correlated allele frequencies were used (Falush et al. 2003). We calculated the probability that there were from $K=I$ to 10 populations (the total number of sites for which microsatellite data were available) and ran five independent simulations for each K. Analyses were performed using an initial burn-in of 50,000 steps followed by $10^{6}$ Markov-chain Monte Carlo analysis sweeps. To infer a most likely $K$ from the log probability of the data LnP (D), we used an ad hoc statistic called $\Delta K$ that calculates the second order rate of change of LnP (D) between the values of $K$ (Evanno et al. 2005). This procedure was implemented using the STRUCTURE HARVESTER web site (Earl and VonHoldt 2012). The results of five replicate runs for each value of $K$ were combined using the Greedy algorithm (Greedy option 2 with 1,000 repeats) of CLUMPP, version 1.1.2 (Jakobsson and Rosenberg 2007), and summary outputs for each value of $K$ were displayed graphically using DISTRUCT, version I.I (Rosenberg 2004).

To explore the demographic history of the populations using mitochondrial data, we calculated Tajima's D statistic (Tajima 1989) and Fu's $F_{\mathrm{S}}$ and $R_{2}$ statistics (Ramos-Onsins and Rozas 2002) with DnaSP 5.10.01 (Librado and Rozas 2009). The $D$ statistic was calculated at the primary level (populations with $n>4$ ) and at the secondary level. A non-significant $D$ value implies no deviation from the neutral model and would indicate that the size of a population had remained largely stable throughout its history (Yang et al. 2012). Significant deviations are indicative of nonneutrality, but the causes can be difficult to distinguish. Thus, positive values of $D$ may indicate positive selection, balancing selection or population size reduction (Perfectti et al. 2009), and negative values, if the marker is deemed neutral, may suggest population expansion after a bottleneck (Küpper et al. 2012). Fu's $F_{S}$ statistic is based on the probability of having a number of haplotypes greater than or equal to the observed number of samples drawn from a population of a constant size, and the $R_{2}$ statistic is based on the difference between the number of singleton mutations and the average number of nucleotide differences (Pilkington et al. 2007). Fu's $F_{\mathrm{S}}$ and $R_{2}$ statistics have the greatest power to detect population expansion for non-recombining regions of the genome under a variety of different circumstances, especially when population sample sizes are large $\left(>50, F_{\mathrm{S}}\right)$ or small (approximately 10, $R_{2}$ ) (Ramos-Onsins and Rozas 2002). We calculated $F_{S}$ for the primary populations and at the secondary level when $n \geq 20$ and calculated $R_{2}$ for the primary populations with small sample sizes $(5<n<20)$. The significance of $F_{\mathrm{S}}$ and $R_{2}$ were obtained by examining the null distribution of 5,000 coalescent simulations. Significantly negative $F_{\mathrm{S}}$ values or significantly positive $R_{2}$ values were indicative of a population expansion.

We tested for an excess of heterozygotes beyond that expected in a population at mutationdrift equilibrium, which is indicative of recent population bottlenecks, using BOTTLENECK 1.2 software (Cornuet and Luikart 1996). Analyses were performed for five populations with at least 10 individuals (Central Galicia, South Galicia, North Portugal, Central Portugal and Cataluña) and were also evaluated separately for Atlantic and Mediterranean birds. We used both the stepwise mutation model (SMM) and the two-phase model (TPM) to perform the Wilcoxon 1-tailed test, which is most powerful when using less than 20 loci (Piry et al. 1999). Using TPM, we fixed 
$95 \%$ single-step mutations and a variance among multiple steps of 12 (Piry et al. 1999). In all cases 10,000 simulation replicates were performed.

Isolation-by-distance among individuals was tested using Mantel tests as implemented in the program Alleles In Space (Miller 2005). Analyses were performed for microsatellite data considering all birds. $P$ values were obtained after 1,000 randomisations.

Using microsatellite data, the gene flow was measured using the $\mathrm{Nm}$ index (Lynch and Crease 1990) and was estimated between populations using GENETIX software (Belkhir et al. 2001). Nm values between $\mathrm{o}$ and $\mathrm{I}$ indicate low gene flow, and $\mathrm{Nm}$ values greater than $\mathrm{I}$ indicate high gene flow (Galacatos et al. 2002).

\section{Results}

\section{Genetic diversity patterns}

Nine haplotypes were observed among the 96 individuals examined for mitochondrial sequences (Table $\mathrm{S}_{2}$ ). Of the 631 positions analysed, eight were polymorphic and five were parsimony informative (Table S2). Haplotype Ch-1 was the most frequent $(n=77)$ in all localities, and there were three unique haplotypes. The nucleotide frequencies were 0.281 (A), 0.256 (T), $0.328(\mathrm{C})$ and $0.132(\mathrm{G})$. The transition / transversion ratios were $k_{1}=3.284$ (purines) and $k_{2}=1.429$ (pyrimidines). The overall transition / transversion bias was $R=0.885$, where $R=\left[\mathrm{A}^{*} \mathrm{G}^{*} k_{1}+\right.$ $\left.\mathrm{T}^{*} \mathrm{C}^{*} k_{2}\right] /\left[(\mathrm{A}+\mathrm{G})^{*}(\mathrm{~T}+\mathrm{C})\right]$. The haplotype and nucleotide diversities were lowest in the southern and eastern populations, and the highest values were found in the Central Portugal population (Table I).

MICRO-CHECKER did not detect allele dropout or stutter bands. Seven of 80 combinations analysed (Io locations x 8 loci) contained null alleles $(P<0.20, n=6, P=0.35 n=1)$. Ten of 80 tests performed for deviation from HWE proportions were statistically significant before applying the Benjamini and Hochberg corrections for multiple comparisons. After correction, one of 80 combinations showed a departure from $\operatorname{HWE}(P<0.000625)$. Thirteen of 280 loci-pair-location combinations showed linkage disequilibrium before correcting for multiple comparisons. After correction, seven combinations showed significant linkage between loci $(P<0.00125)$.

The observed heterozygosity was lower than expected for all populations, with the exception of North Galicia and North Portugal. The mean number of alleles per locus varied from 3.75 to 1o across the populations. The allelic richness, corrected for simple size using rarefaction, ranged from 3.75 in Castellon to 4.75 in South Portugal (Table 1) and was 8.96 and 8.63 for the Atlantic and Mediterranean areas, respectively. The private allelic richness ranged from 0.14 for North Portugal to 0.41 for Central Galicia.

\section{Genetic structure and population history}

After Benjamini and Hochberg corrections for multiple comparisons, pairwise $\Phi_{\mathrm{ST}}$ values among all sites were significant in four cases, but $F_{S T}$ values did not show significant values (Table 2). Thus, pairwise $\Phi_{\mathrm{ST}}$ and $F_{\mathrm{ST}}$ values did not support geographic structure. A priori groupings of Kentish Plover sites were poorly supported by AMOVA. All groupings of the sites showed very low explained percentages of the variation in the microsatellite loci frequencies (Table 3).

STRUCTURE indicated that the most likely partitioning of the data exists for the $K=4$ case, with $\Delta K$ ranged from $0.868(K=8)$ to $21.499(K=4)$. However when visualised, proportions of individual genomes assigned to each cluster suggest that there is no population structure (Figure 2). The Mantel test did not show significant correlation between genetic and geographic distances ( $\mathrm{r}=0.0002, P=0.51)$.

The Tajima values were not significant at the primary level or when grouped by Mediterranean $(D=-1.164)$ and Atlantic coast $(D=-1.671)$. At the primary level, two populations showed significant Fu's $F_{\mathrm{S}}$ or $R_{2}$ values: Central Galicia $\left(F_{\mathrm{S}}=-1.543, P<0.05\right)$ and Central Portugal 
Table 2. Pairwise $\Phi_{\mathrm{ST}}$ values among sites at mtDNA control region (above diagonal) and $F_{\mathrm{ST}}$ values at microsatellite loci (below diagonal). *Significant values at $\alpha=0.05$ level after Benjamini and Hochberg correction showed in bold type. Population names as Table 1 .

\begin{tabular}{lllllllllll}
\hline Site & NG & CG & SG & NP & CP & SP & HU & AL & CS & CT \\
\hline NG & - & -0.0025 & -0.0384 & 0.1262 & 0.1524 & -0.1321 & -0.0660 & -0.0526 & 0.0000 & -0.0227 \\
CG & -0.0480 & - & -0.0069 & -0.0147 & $\mathbf{0 . 3 8 5 2 ^ { * }}$ & -0.1576 & -0.0770 & -0.1022 & -0.0706 & -0.0263 \\
SG & 0.0039 & -0.0016 & - & 0.0576 & 0.2178 & -0.1111 & -0.0248 & -0.0526 & -0.0169 & -0.0019 \\
NP & 0.0499 & 0.0114 & -0.0347 & - & $\mathbf{0 . 3 8 9 4}$ & 0.0000 & 0.0156 & 0.0000 & 0.0000 & -0.0196 \\
CP & 0.0175 & 0.0192 & -0.0263 & -0.0321 & - & 0.2275 & $\mathbf{0 . 2 6 2 2}$ & 0.2727 & 0.3048 & $\mathbf{0 . 3 2 4 3}$ \\
SP & -0.0156 & -0.0070 & -0.0105 & -0.0027 & 0.0168 & - & -0.1748 & 0.0000 & 0.0000 & -0.1870 \\
HU & 0.0167 & 0.0354 & 0.0616 & 0.1171 & 0.0927 & 0.0060 & - & -0.1089 & -0.0687 & -0.0507 \\
AL & 0.0006 & 0.0176 & 0.0599 & 0.1115 & 0.0950 & -0.0429 & -0.0451 & - & 0.0000 & -0.1253 \\
CS & 0.0148 & 0.0347 & 0.0593 & 0.1056 & 0.0867 & -0.0742 & -0.0439 & -0.0498 & - & -0.0891 \\
CT & -0.0574 & -0.0007 & 0.0486 & 0.0846 & 0.0606 & 0.0419 & 0.0805 & 0.0351 & 0.0947 & - \\
\hline
\end{tabular}

$\left(R_{2}=0.117, P<0.05\right)$. At the secondary level, only the Atlantic coast showed significant values $\left(F_{\mathrm{S}}=-6.044, P<0.001\right)$. Fu's $F_{\mathrm{S}}$ value for Galician birds was also significant $\left(F_{\mathrm{S}}=-3.527, P<0.01\right)$.

The bottleneck tests did not yield evidence for population reduction, and the coalescent analyses were non-significant at both the primary and secondary levels. The gene flow between locations was high. For all comparisons $(n=45)$, the $N m$ values were greater than 3 and were greater than 4 for 42 comparisons (Table $\mathrm{S}_{3}$ ).

\section{Discussion}

The absence of significant differences in the $\Phi_{\mathrm{ST}}$ and $F_{\mathrm{ST}}$ comparisons and the low percentage of variation explained by the AMOVA analyses are in line with the panmixia scenario described at the continental scale for the Kentish Plover (Küpper et al. 2012) and the Snowy Plover (Funk et al. 2007). Moreover, we found a lack of an isolation-by-distance pattern. STRUCTURE identified four groups for the Iberian coast, but there was no association between groups and geography and the $\Delta K$ varied weakly. The correlated allele frequency model used in this study often achieves better performance, and it is easier to overestimate $K$ (Falush et al. 2003). These facts suggest that there is no population structure and that the sample sites should be lumped into a single group (Pritchard et al. 2000).

Facing the doubts around the Spanish and Portuguese population trends (BirdLife International 2004b, Figuerola et al. 2004, Felgueiras 2008, Delany et al. 2009) our results do not support the

Table 3. Analysis of molecular variance (AMOVA) at microsatellite loci with Kentish plover sampling sites grouped in different ways. Groups: A, Atlantic coast-Mediterranean coast; B, Central and northern Atlantic coast-southern Atlantic coast- Mediterranean coast; C, North-western Spanish coast (Galicia)-Portugal and Spanish southern Atlantic coast (Huelva)-Mediterranean coast.

\begin{tabular}{lllrr}
\hline Groups & Number of groups & Variance components & $\%$ variation & $P$-value \\
\hline A & 2 & Among groups & 0.51 & 0.069 \\
& & Among populations & 1.43 & 0.027 \\
& \multirow{3}{*}{3} & Within populations & 98.06 & 0.006 \\
& & Among groups & 0.58 & 0.028 \\
& \multirow{2}{*}{3} & Among populations & 1.29 & 0.095 \\
C & Within populations & 98.13 & 0.007 \\
& & Among groups & 0.38 & 0.061 \\
& & Among populations & 1.37 & 0.110 \\
& Within populations & 98.2 & 0.009 \\
\hline
\end{tabular}




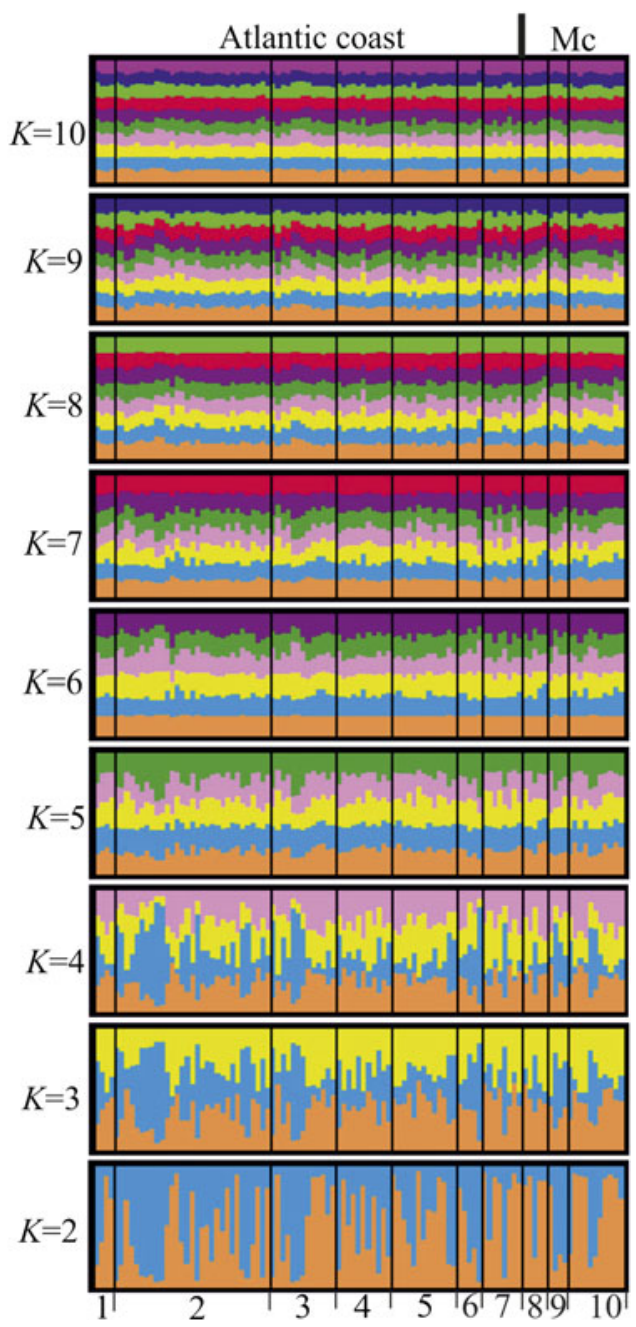

Figure 2. Microsatellite data analysis with STRUCTURE program. Bar plot where each vertical line represents one bird; the different colours refer to the individual's genomic proportion assigned from $K=2$ to $K=10$. Abbreviations: MC, Mediterranean coast. A priori populations: 1 , North Galicia; 2, Central Galicia; 3, South Galicia; 4, North Portugal; 5, Central Portugal; 6, South Portugal; 7, Huelva; 8, Alicante; 9, Castellón; 10, Cataluña.

recent decline hypothesis because there is no bottleneck evidence, but there is evidence of population expansion for two Atlantic populations, Central Galicia and Central Portugal, and for the Atlantic coast population at a secondary level. An evaluation of trends for the Galician breeding plovers from 1988 to 2010 showed a decline until 2004 followed by a moderate increase (Vidal and Domínguez 2013). After 2004, the Galician birds reacted to the Prestige oil spill by increasing population numbers, avoiding the most affected areas and moving to new breeding beaches (Vidal and Domínguez 2013). Population growth was attributed to the combination of three main factors: successful management strategies undertaken at many of the Galician Kentish Plover breeding beaches after the Prestige oil spill, changes occurring in the spatial distribution of the breeding pairs and immigration of birds from other sites (Vidal and Domínguez 2013). 
Küpper et al. (2012) offer two explanations for high gene flow between Kentish Plover populations: firstly, temporary breeding habitats, often unstable and only suitable for a fraction of the available breeding time promoting mobility of the breeders, and secondly, high breeding dispersal (hundreds of kilometres apart) of re-nesting females, suggesting a prominent role for the last one. In the Galician population neither of these explanations seems to be useful. Galician Kentish Plovers breed solely on beaches, a suitable and more predictable habitat during the breeding period than ephemeral inland wetlands (Kraaijeveld 2008) or salt marshes and fish ponds (Küpper et al. 2012). Thus, nesting pairs spend the entire season on the same beach or, at most, occasionally visit neighbouring beaches (Domínguez and Vidal 2008). Female movements during the breeding period are related to polyandrous behaviour, and successful females abandon the brood in the care of the male to re-mate and re-nest, sometimes at sites several kilometres apart (Székely and Lessells 1993, Amat et al. 1999). However, this behaviour is uncommon in the Galician population, mainly due to the extremely low hatching success (Domínguez and Vidal 2003, 2008). The unsuccessful nesters show a high degree of mate fidelity and re-nest at the same beach or nearby and this same behaviour is observed in the sparse successful females (Domínguez and Vidal 2008 and unpubl. data).

What is then responsible for the demography of the Galician Kentish Plover population? Re-sighting data confirmed the dispersal of individuals between the Galician and Portuguese coasts (Domínguez and Vidal 2008). These data are scarce and mainly correspond to wintering individuals, but it seems that the same pattern could be repeated in the breeding period, and the number of dispersers would be enough to assess the genetic connectivity. A small number of dispersing individuals per generation is sufficient to prevent genetic differentiation between two populations (Funk et al. 2007). Dispersal can contribute significantly to population growth rates, gene flow and, ultimately, species persistence. However, taking into account the breeding parameters and high site fidelity of the Galician population, dispersal would be asymmetric. Thus, the Portuguese and Galician Kentish Plover populations would be demographically connected, as that term refers to those in which population growth rates or specific vital rates (survival and birth rates) are affected by immigration or emigration (Runge et al. 2006, Mills 2007). The importance of demographic connectivity is clear when the elimination of immigration results in a shift from stable or positive population growth to negative population growth, and immigration can be critical to the persistence of sink populations by compensating for low local recruitment (Lowe and Allendorf 2010). Demographic connectivity is of central importance to basic population biology (Nichols et al. 2000, Runge et al. 2006) and to species persistence in human-modified systems (Griffin and Mills 2009, Peery et al. 2010). We hypothesise that the Kentish Plover population along the Galician coast represents a sink that would decline in the absence of immigration from other population(s). Moreover, this sink hypothesis could explain the extinction of the Cantabrian population that may have depended on the immigration of plovers from Galician beaches. This Cantabrian population disappeared in the late 1970 shen the Galician population was estimated at less than 47 pairs (de Souza and Domínguez 1989).

The rigorous identification of source-sink dynamics requires detailed information about a population or patch-specific estimates of fitness (natality and survival rates) as well as on the rates of movement among populations. It is often possible to estimate rates of reproduction and survival, but estimating the immigration and emigration rates by marking individuals in the population of origin and recapturing them in a destination population is inherently difficult for most natural populations (Macdonald and Johnson 2001).

\section{Implications for conservation and management}

An accurate estimate of the level and spatial distribution of the genetic diversity of rare and endangered species provides fundamental information that can be used for designing appropriate conservation programs. Source-sink dynamics for Kentish Plover populations would have important conservation implications because sink populations are dependent on the continued persistence 
of source populations. We found no genetic structure in Kentish Plovers on a coastal Iberian scale, and we emphasise the need for further studies on demographic connectivity through a capture-mark-recapture program or geolocation in order to ascertain the viability of endangered populations. The management guidelines provided in the Galician Kentish Plover Recovery Plan (Decree 9/2014, January 23) consider the Galician population alone. We demonstrate the need to consider both the Galician and Portuguese Kentish Plover populations and their breeding areas to be a single management unit, and population goals and objectives should be based on that premise. Ultimately, the proper and successful implementation of a management strategy could promote the recolonization of the Cantabrian coast, a peripheral area in the Atlantic Iberian Kentish Plover distribution.

\section{Supplementary Material}

The supplementary materials for this article can be found at journals.cambridge.org/bci

\section{Acknowledgements}

We are grateful to Ana Amezcua for help with the genetic analyses. Funding for the fieldwork and analyses was partially provided by Xunta de Galicia. The laboratory work was conducted at The University of Navarra. We thank Juan Aguilar Amat and an anonymous reviewer for their useful suggestions. All samples were collected under appropriate licenses in accordance with national legal, ethical and welfare regulations.

\section{References}

Albaigés, J., Morales-Nin, B. and Vilas, F. (2006) The Prestige oil spill: A scientific response. Mar. Pollut. Bull. 53: 205-207.

Álvarez-Balbuena, F. (2000) Aves raras y escasas en Asturies. Avilés: Coordinadora Ornitológica Asturiana.

Amat, J. A. (2012) Chorlitejo patinegro. In L. M. Carrascal and A. Salvador, eds. Enciclopedia virtual de los vertebrados Españoles. Madrid: Museo Nacional de Ciencias Naturales.

Amat, J. A., Fraga, R. M. and Arroyo, G. M. (1999) Replacement clutches by Kentish Plovers. Condor 101: 746-751.

Avise, J. C. (2000) Phylogeography: The history and formation of species. Cambridge, USA: Harvard University Press.

Ballesteros, T. and Torre, I. (1993) Incidencia de la predación sobre el fracaso de las puestas de Chorlitejo patinegro Charadrius alexandrinus en el Delta del Llobregat. Bull. GCA 10: 59-61.

Belkhir, K., Borsa, P., Chikhi, L., Raufaste, N. and Bonhomme, F. (2001) GENETIX 4.02, logiciel sous Windows TM pour la génétique des populations. Montpellier: Université de Montpellier II. Laboratoire Génome, Populations, Interactions, CNRS UMR 5000.

Benjamini, Y., Drai, D., Elmer, G., Kafkafi, N. and Golani, I. (2001) Controlling the false discovery rate in behavior genetics research. Behav. Brain. Res. 125: 279-284.

BirdLife International (2004a) Birds in the European Union: a status assessment. Wageningen, The Netherlands: BirdLife International.

BirdLife International (2004b) Birds in Europe: population estimates, trends and conservation status. Wageningen, The Netherlands: BirdLife International.

Cornuet, J. M. and Luikart, G. (1996) Description and power analysis of two tests for detecting recent population bottlenecks from allele frequency data. Genetics 144: 2001-2014.

de Souza, J. A. and Domínguez, J. (1989) Efectivos y distribución del Chorlitejo Patinegro (Charadrius alexandrinus) en Galicia. Ecología 3: 305-311.

Delany, S., Scott, D. A., Dodman, T. and Stroud, D. A., eds. (2009) An atlas of wader populations in Africa and western Eurasia. 
Wageningen, The Netherlands: Wetlands International.

Domínguez, J. and Vidal, M. (2003) Influencia del investigador en el éxito reproductivo del Chorlitejo Patinegro Charadrius alexandrinus. Ardeola, 50: 15-19.

Domínguez, J. and Vidal, M. (2008) Plan de Conservación del Chorlitejo patinegro (Charadrius alexandrinus) en Galicia. Santiago de Compostela: Consellería de Medio Ambiente e Desenvolvemento Sostible.

Earl, D. A. and VonHoldt, B. M. (2012) STRUCTURE HARVESTER: a website and program for visualizing STRUCTURE output and implementing the Evanno method. Conserv. Genet. Res. 4: 359-361.

Evanno, G., Regnaut, S. and Goudet, J. (2005) Detecting the number of clusters of individuals using the software STRUCTURE: a simulation study. Mol. Ecol. 14: 2611-2620.

Excoffier, L. and Lischer, H. E. L. (2010) Arlequin suite ver. 3.5: A new series of programs to perform population genetics analyses under Linux and Windows. Mol. Ecol. Res. 10: 564-567.

Falush, D., Stephens, M. and Pritchard, J. K. (2003) Inference of population structure using multilocus genotype data: Linked loci and correlated allele frequencies. Genetics 164: 1567-1587.

Felgueiras, M. (2008) Charadrius alexandrinus. Pp. 216-217 in Equipa Atlas, ed. Atlas das Aves nidificantes em Portugal (1999-2005). Lisboa: Assirio \& Alvim.

Ferns, P. (1992) Bird life of coasts and estuaries. Cambridge, UK: Cambridge University Press.

Figuerola, J., Amat, J. A. and Díaz, J. A. (2004) Chorlitejo patinegro Charadrius alexandrinus. Pp. 228-230 in A. Madroño, C. González C and J. C. Atienza, eds. Libro Rojo de las aves de España. Madrid: Dirección General para la Biodiversidad-SEO/BirdLife.

Fraga, R. M. and Amat, J. A. (1996) Breeding biology of a Kentish Plover (Charadrius alexandrinus) population in a inland saline lake. Ardeola 43: 69-85.

Frankham, R. (2005) Genetics and extinction. Biol. Conserv. 126: 131-140.

Funk, W., Mullins, T. and Haig, S. (2007) Conservation genetics of snowy plovers
(Charadrius alexandrinus) in the Western Hemisphere: population genetic structure and delineation of subspecies. Conserv. Genet. 8: 1287-1309.

Galacatos, K., Cognato, A. I. and Gold, R. (2002) Population genetic structure of two water strider species in the Ecuadorian Amazon. Freshwater Biol. 47: 391-399.

Griffin, P. C. and Mills, L. S. (2009) Sinks without borders: snowshoe hare dynamics in a complex landscape. Oikos 118: 1487-1498.

Guo, S. W. and Thompson, E. A. (1992) Performing the exact test of Hardy-Weinberg proportions for multiple alleles. Biometrics 53:325-338.

Hall, T. A. (1999) BioEdit: a user-friendly biological sequence alignment editor and analysis program for Windows 95/98/NT. Nucl. Acids Symp. Ser. 41: 95-98.

Hanane, S. (2011) Breeding ecology of Kentish Plovers Charadrius alexandrinus in rocky and sandy habitats of north-west Morocco (North Africa). Ostrich 82: 217-223.

IUCN (2013) IUCN Red List of Threatened Species. Version 2013.1. www.iucnredlist. org. Downloaded on 15 October 2013.

Jakobsson, M. and Rosenberg, N. A. (2007) CLUMPP: a cluster matching and permutation program for dealing with label switching and multimodality in analysis of population structure. Bioinformatics 23 : 1801-1806.

Joseph, L., Pessa, E. P. and Christidis, L. (1999) Phylogeny and biogeography in the evolution of migration: shorebirds of the Charadrius complex. J. Biogeogr. 26: 329-342.

Kalinowski, S. T. (2005) HP-RARE 1.0: a computer program for performing rarefaction on measures of allelic richness. Mol. Ecol. Notes 5: 187-189.

Kosztolanyi, A., Javed, S., Küpper, C., Cuthill, I. C. Al Shamsi, A. and Székely, T. (2009) Breeding ecology of Kentish Plover Charadrius alexandrinus in an extremely hot environment. Bird Study 56: 244-252.

Kraaijeveld, K. (2008) Non-breeding habitat preference affects ecological speciation in migratory waders. Naturwissenschaften 95 : 347-354.

Küpper, C., Horsburgh, G. J., Dawson, D. A., French-Constant, R., Székely, T. and Burke, T. 
(2007) Characterization of 36 polymorphic microsatellite loci in the Kentish plover (Charadrius alexandrinus) including two sex-linked loci and their amplification in four other Charadrius species. Mol. Ecol. Notes 7: 35-39.

Küpper, C., Edwards, S. V., Kosztolanyi, A., Alrashidi, M., Burke, T., Herrmann, P., Argüelles-Tico, A., Amat, J. A., Amezian, M., Rocha, A., Hötker, H., Ivanov, A., Chernicko, J. and Székely, T. (2012) High gene flow on a continental scale in the polyandrous Kentish plover Charadrius alexandrinus. Mol. Ecol. 21: 5864-5879.

Lang, B. and Typlot, A. (1985) Analyse des fiches de nid du Gravelot à Collier Interrompu. Le Cormoran 28: 330-335.

Librado, P. and Rozas, J. (2009) DnaSP v5: A software for comprehensive analysis of DNA polymorphism data. Bioinformatics 25: 1451-1452.

Lowe, W. H. and Allendorf, F. W. (2010) What can genetics tell us about population connectivity? Mol. Ecol. 19: 3038-3051.

Lynch, M. and Crease, T. J. (1990) The analysis of population survey data on DNA sequence variation. Mol. Biol. Evol. 7: 377-394.

Macdonald, D. W. and Johnson, D. P. (2001) Dispersal in theory and practice: consequences for conservation biology. Pp. 358-372 in J. Clobert, A. A. Dhondt and J. D. Nichols, eds. Dispersal. Oxford: Oxford University Press.

Miller, M. P. (2005) Alleles in Space: Computer software for the joint analysis of interindividual spatial and genetic information. J. Hered. 96: 722-724.

Mills, L. S. (2007) Conservation of wildlife populations: Demography, genetics, and management. Malden, MA: Blackwell.

Nichols, J. D., Hines, J. E., Lebreton, J. D. and Pradel, R. (2000) Estimation of contributions to population growth: A reverse-time capture-recapture approach. Ecology 81: 3362-3376.

Norte, A. C. and Ramos, J. A. (2004) Nest-site selection and breeding biology of Kentish plover Charadrius alexandrinus on sandy beaches of the Portuguese west coast. Ardeola 51: 255-268.

Oltra, C. and Gómez, M. A. (1995) Kentish Plover breeding population in two beaches of Spanish Levante. WSG Kentish Plover Project Newsletter 4: 10.

Palsbøll, P. J. (2010) Genetic analyses of historic and modern marbled murrelets suggest decoupling of migration and gene flow after habitat fragmentation. Proc. R. Soc. B 277: 697-706.

Peery, M. Z., Hall, L. A., Sellas, A., Beissinger, S. R., Moritz, C., Bérubé, M., Raphael, M. G., Nelson, S. K., Golightly, R. T., McFarlaneTranquilla, L., Newman, S. and Perfectti, F., Picó, F. X. and Gómez, J. M. (2009) La huella genética de la selección natural. Ecosistemas 18: 10-16.

Pilkington, M. M., Wilder, J. A., Mendez, F. L., Cox, M. P., Woerner, A., Angui, T., Kingan, S., Mobasher, Z., Batini, C., Destro-Bisol, G., Soodyall, S., Strassmann, B. I. and Hammer, M. F. (2007) Contrasting signatures of population growth for mitochondrial DNA and $Y$ chromosomes among human populations in Africa. Mol. Biol. Evol. 25: 517-525.

Piry, S., Luikart, G. and Cornuet, J-M. (1999) BOTTLENECK: A computer program for detecting recent reductions in the effective population size using allele frequency data. J. Hered. 90: 502-503.

Pritchard, J. K., Stephens, M. and Donnelly, P. (2000) Inference of population structure using multilocus genotype data. Genetics 155: 945-959.

Ramos-Onsins, S. E. and Rozas, J. (2002) Statistical properties of new neutrality tests against population growth. Mol. Biol. Evol. 19: 2092-2100.

Rosenberg, N. A. (2004) Distruct: a program for the graphical display of population structure. Mol. Ecol. Notes 4: 137-138.

Runge, J. P., Runge, M. C. and Nichols, J. D. (2006) The role of local populations within a landscape context: Defining and classifying sources and sinks. Am. Nat. 167: 925-938.

Smith, L. M. and Burgoyne, L. A. (2004) Collecting, archiving and processing DNA from wildlife samples using FTA $^{\circledR}$ databasing paper. BMC Ecol. 4: 4.

Székely, T. (1992) Reproduction of Kentish Plover (Charadrius alexandrinus) in grasslands and fish-ponds: the habitat malassessment hypothesis. Aquila 99: 59-67. 
Székely, T. and Lessells, C. M. (1993) Mate change by Kentish Plovers Charadrius alexandrinus. Ornis Scand. 24: 317-322.

Tajima, F. (1989) Statistical method for testing the neutral mutation hypothesis by DNA polymorphism. Genetics 123: 585-595.

Toral, G. M. and Figuerola, J. (2012) Nest success of Black-winged Stilt Himantopus himantopus and Kentish Plover Charadrius alexandrinus in rice fields, southwest Spain. Ardea 100: 29-36.

Van Oosterhout, C., Hutchinson, W. F., Wills, D. P. M. and Shipley, P. (2004) MICROCHECKER: software for identifying and correcting genotyping errors in microsatellite data. Mol. Ecol. Notes 4: 535-538.

Verkuil, Y. I., Piersma, T., Jukema, J., Hooijmeijer, J. C. E. W., Zwarts, L. and Baker, A. J. (2012) The interplay between habitat availability and population differentiation: a case study on genetic and morphological structure in an inland wader (Charadriiformes). Biol. J. Linn. Soc. 106: 641-656.

Vidal, M. and Domínguez, J. (2013) Long-term population trends of breeding Kentish Plovers (Charadrius alexandrinus) in Northwestern Spain under the effects of a major oil spill. Bird Conserv. Internatn. 23:386-397.

Wright, S. (1965) The interpretation of population structure by F-statistics with special regard to systems of mating. Evolution 19: 395-420.

Yang, M., Yang, Y., Cui, D., Fickenscher, G., Zinner, D., Roos, C. and Brameier, M. (2012) Population genetic structure of Guizhou snub-nosed monkeys (Rhinopithecus brelichi) as inferred from mitochondrial control region sequences, and comparison with $R$. roxellana and R. bieti. Am. J. Phys. Anthropol. 147: 1-10.

\title{
MARÍA VIDAL, JESÚS DOMÍNGUEZ*
}

Department of Zoology and Physical Anthropology, Faculty of Biology, University of Santiago de Compostela, E-15782 Santiago de Compostela, Spain.

\section{MARÍA A. HERNÁNDEZ}

Department of Zoology and Ecology, Faculty of Science, University of Navarra, E-31080 Pamplona, Spain.

\author{
ANTONIO LUIS \\ Department of Biology, University of Aveiro, 3810-193 Aveiro, Portugal. \\ *Author for correspondence; e-mail: jesus.dominguez@usc.es
}

Received 12 July 2013; revision accepted 24 June 2014; Published online 19 August 2014 